\title{
Does Airbnb Love Barcelona? The Struggle of Platform Capitalism for Gaining Public Opinion
}

\author{
José A Mansilla ${ }^{1 *}$ and Alan Quaglieri ${ }^{2}$ \\ ${ }^{1}$ Observatory of Anthropology of Urban Conflict (OACU), Spain \\ ${ }^{2}$ Research Group for Territorial Analysis and Tourism Studies (GRATET) - Rovira i Virgili University, Spain
}

Submission: June 27, 2018; Published: July 16, 2018

*Corresponding author: José A Mansilla, PhD in Social Anthropology, Observatory of Anthropology of Urban Conflict, 08005 Barcelona, Spain, Email: joseamansilla@hotmail.com

Keywords: Airbnb; Local; Community; Neighborhood; Newspeak; Cities; Commodifying; Platform capitalism; Cosmopolitanism; Digital; Analog; Economy; Host; Authentic; Guests; De-commodify; Social Life; Collaborative

\section{Opinion}

Airbnb has made a leap from digital to analog. This leap has been made in prime time and in one of the most listened radio stations in Spain. However, what does a company like Airbnb investing in advertising in a traditional media when it presents always itself as one of the main stars of the new economy? Moreover, does not know Airbnb that cannot continue with their activities in the Catalan capital without worsening its relationship with the City Council, or maybe this campaign does not go aimed at attracting customers - "host" in the sharing economy newspeak- but at much more diffuse and less obvious objective?

Let's go step by step. The Airbnb's radio spots gather all the stereotypes of the platform capitalism [1], that is, good vibes, cosmopolitanism, taste of the neighborhood, experience, local cuisine, love and respect for life in the city. The sequence is always the same: one or several men or women, young voices, sometimes with a slight foreign accent, are presented as the best ambassadors of Barcelona. In the background rumba music and, in the foreground, a list of magnificent intentions and opportunities. For the "guests", another element of the Airbnb newspeak: to know, from the hand of a resident of the city, those aspects and corners that do not appear in the guides, a contact with the "authentic", out of the beaten tracks, etc. For the aforementioned hosts: the possibility to make ends meet through some extra income, to become ambassadors of their city, to connect with the rest of the world... In all this, Airbnb practically does not appear on the scene. All the importance in this festival of cosmopolitanism is for "hosts" and "guests", while the Californian company just appears in the credits as a mere institutional sponsor.
These actions do not respond to a communication policy aimed at attracting new users or customers. In an almost monopolistic situation like the one Airbnb enjoys, as well as several other so-called "collaborative" platforms in different sectors, the main threats to its business are located outside the sacred perimeter of the market. If on the one hand, discreet but intense lobbying activities are accredited in the salons of the legislative power, on the other hand, it is necessary to convince the public opinion of the model's virtues and encourage it to accept possible changes in the regulations that are favorable to the cause.

To lead citizens to empathize with the champions of this revolution, the story must be purified of all the conflictive elements. In this way, the alleged synergies that the so-called home sharing is able to awaken are magnified. Airbnb always suggests a win-win situation where nobody loses anything and everyone, in one way or another, has something to gain, even the mere consolation of contributing to a better world. In fact, one of the main challenges of the collaborative rhetoric has been, precisely, to hide behind collective references -the neighborhood, the community, the neighbors, the city- the deeply individualistic nature of tourist rental practices. Besides, the conflict that its popularization entails within the framework of the conflicting housing market in Barcelona is also hidden. An ambitious and necessary challenge in order to redress a public opinion that has seen how the explosion of the Airbnb phenomenon in recent years has coincided with a stage of intense acceleration and generation of inequalities by the real estate sector of the city [2].

We could argue over and over about what came first. If the changes in the demand realized by tourists, that is, the search 
for horizons that, finally, were not in distant beaches and exotic destinations, but in the streets and squares of many of the popular neighborhoods of the cities. Alternatively, if what Airbnb supposes is a new circuit, in the form of daily life, by which Capital can flow always in search of new investments that guarantee higher returns.

What cannot be doubted is that, when Airbnb shows itself with its best suit for improving its relationship with the city, claiming the right of everybody to share the city, what it is really (pro)claiming is the possibility of its sale. Loving Barcelona is not to share it with the world, but to de-commodify its social life.

\section{References}

1. Srnicek N (2016) Platform capitalism Place (1 $1^{\text {st }}$ edn), John Wiley \& Sons, New Jersey, USA.

2. Quaglieri A, Arias A (2016) Unraveling Airbnb: Urban perspectives from Barcelona. In: Russo A, Richards G (Eds.), Reinventing the Local in Tourism: Producing, Consuming and Negotiating Place (1st edition), Channel View Publications, Buffalo, NY, USA, pp. 209-228.

\section{Your next submission with Juniper Publishers will reach you the below assets}

- Quality Editorial service

- Swift Peer Review

- Reprints availability

- E-prints Service

- Manuscript Podcast for convenient understanding

- Global attainment for your research

- Manuscript accessibility in different formats

( Pdf, E-pub, Full Text, Audio)

- Unceasing customer service

Track the below URL for one-step submission https://juniperpublishers.com/online-submission.php 